\title{
Solidariedade e natureza humana
}

\author{
Solidarity and human nature \\ Luis Miguel dos Santos Luzio* \\ Bernardo Carlos Spaulonci Chiachia Matos de Oliveira**
}

\begin{abstract}
Resumo:
O conceito de solidariedade povoa o inconsciente coletivo e é usualmente relacionado a algo consensual, ligado aos valores mais elementares do gênero humano. Porém, ampliar esse entendimento conduz-nos a visões mais complexas. Seria a solidariedade humana condicionada pela natureza biológica ou uma questão cultural que ultrapassa qualquer possível determinismo biológico? Este estudo busca analisar o fenômeno da solidariedade e sua correlação com a vida em sociedade sob a perspectiva da complexidade, por meio de uma análise transversal, visando abarcar o fenômeno em questão sob diferentes olhares. Para tanto, recorreu-se à sociobiologia e a sua interpretação nas ciências sociais. Buscou-se, assim, renunciar à ideia ou ao projeto de solução definitiva e totalizadora, aproximando-se dos pressupostos do pensamento complexo, que se apoiam justamente na superação de um único princípio organizativo, ou de uma única causa, para a explicação do mesmo fenômeno. Percebeu-se, então, a necessidade de novas experiências societais, que possam obstaculizar o avanço do paradigma competitivo individualista como única alternativa, com destaque para as experiências de economia solidária e organizações do terceiro setor que apresentam uma nova lógica empresarial, uma terceira força social, entre o estado e o mercado.
\end{abstract}

Palavras-chave: Solidariedade. Sociobilogia. Competição. Cooperação.

\begin{abstract}
:
The concept of solidarity inhabits the collective unconscious and is usually related to something consensual, linked to the most basic values of mankind, but to expand that understanding leads to more complex views. Human solidarity would be conditioned by biological, or cultural issue that goes beyond any possible biological determinism. This study seeks to analyze the phenomenon of solidarity and its correlation with life in society from the perspective of complexity, through a cross-sectional analysis in order to cover the phenomenon in question from different perspectives. For that, we appealed to sociobiology, and the social
\end{abstract}

\footnotetext{
* Doutor em Ciências Sociais pela Pontifícia Universidade Católica de São Paulo - PUC-SP; Mestre em Administração pela Universidade Estadual de Londrina - UEL; Graduado em Economia e Administração, ambos pela Universidade Estadual de Londrina -UEL. Atualmente é Professor Adjunto do Departamento de Administração da Universidade Estadual de Londrina Imig@uol.com.br.

** Graduado em Administração pela Universidade Estadual de Londrina (2007); mestrando em Administração (2010) (Programa de Pós-Graduação em Administração - PPGA-UEL),bolsista CAPES. oliveira.bernardo@gmail.com.
} 
sciences interpretation. We tried to thereby renounce the sole idea and permanent solution, by approaching to the assumptions of complex thinking, which rely precisely to overcome a single organizing principle or a single cause to explain the same phenomenon. It noticed the need of new societal experiences, which would block the advance of competitive individualist paradigm as the sole alternative, highlighting the experiences of the solidarity economy and third sector organizations that have a new business logic, a third social force among the state and the market.

Keywords: Solidarity. Sociobiology. Competition. Cooperation.

\section{Introdução}

Muitas são as definições e perspectivas em relação ao conceito de solidariedade, devendo-se fugir da ideia de consenso ou de um idealismo simplista que tende a obscurecer contradições e embates. No entanto, o ideal da solidariedade povoa o inconsciente coletivo, podendo ser encontrada em diferentes períodos históricos, regiões, culturas e ideologias, ainda que cada um a revista de singularidades o que alimenta o seu pluralismo.

Para conceituar solidariedade, temos que recorrer à própria etimologia da palavra, cuja origem latina remete à solidum, que significa totalidade, soma total, ou ainda, solidus, que significa sólido, maciço, inteiro. Quando se busca a definição sociológica de solidariedade, o Dicionário Michaelis (POLITO, 2009) indica que se trata de uma: "Condição grupal resultante da comunhão de atitudes e sentimentos, de modo a constituir o grupo unidade sólida, capaz de resistir às forças exteriores e mesmo de tornar-se ainda mais firme em face da oposição vinda de fora". No Dicionário Aurélio (FERREIRA, 2010), ainda que haja uma conceituação próxima, chama atenção a expressão "vínculo recíproco" como inerente ao conceito de solidariedade, o que remete à mutualidade e a uma relação de dupla face.

Quando se tenta entender o fenômeno da solidariedade partindo de suas raízes biológicas, encontram-se explicações distintas, que tanto se complementam como se conflitam. Uma das correntes mais fortes dentro da biologia contemporânea parte da explicação darwiniana da evolução via seleção natural das espécies, porém esta tese encontra variados desdobramentos, destacando-se a tese que percebe a evolução como um processo de concorrência entre genes, que tende a privilegiar os mais aptos em 
detrimento dos demais. Outras vertentes, no entanto, dão destaque à capacidade de empatia e cooperação como a principal força motriz da evolução biológica.

Quando a discussão ultrapassa o campo das ciências naturais e adentra na esfera das ciências sociais, aumenta a complexidade de análise e se expõem, de forma mais contundente, as distintas abordagens em torno da questão da solidariedade. Enquanto uma das vertentes explicativas apoia-se na raiz darwiniana para justificar posições individualistas e competitivas como predominantes no gênero humano, de forma contrária, uma segunda corrente privilegia a compreensão dos aspectos culturais, históricos e políticos como determinantes na construção da vida em sociedade. Além do mais, cada uma dessas correntes se desdobra em muita outras, que em alguns casos se complementam e em outros se conflitam.

Pedro Demo (2002) dá uma valiosa contribuição ao expor dois modelos de solidariedade distintos dentro do arcabouço das ciências sociais: a solidariedade de cima e a solidariedade de baixo, em que a primeira parte das elites em relação às classes subalternas como uma concessão voluntária, invariavelmente infectada por efeitos de poder que conduzem à subserviência e à preservação do status quo. De forma contrária, expressa-se a solidariedade de baixo, que parte de propostas emancipatórias das classes marginalizadas que percebem a realidade como campo de conflito entre interesses divergentes, entendendo a exclusão como um fenômeno decorrente da estrutura dominante que obstaculiza a emancipação das camadas populares, que assim se unem em torno de lutas e ideais comuns e em prol da sua própria libertação (DEMO, 2002).

Este artigo busca apresentar a questão da solidariedade sob a perspectiva da complexidade, fazendo uma análise transversal que tenta abarcar o fenômeno sob diferentes olhares. Nesse sentido, houve um esforço em entender a solidariedade dentro da perspectiva biológica, de forma mais específica da sociobiologia, e também sua interpretação dentro das ciências sociais. Percebe-se que os embates não se fazem presentes somente entre distintos campos da ciência, mas também dentro de cada um destes, o que obriga a uma compreensão considerando as múltiplas conexões estabelecidas.

O presente estudo é classificado como de natureza qualitativo-descritiva e bibliográfico, no qual se analisam algumas das principais correntes teóricas dentro das 
ciências biológicas e das ciências humanas, que se debruçam em compreender o fenômeno da solidariedade e como ele se expressa no humano e em seus arranjos societais. Sabe-se, a priori, das limitações desse estudo por se tratar de uma área de fronteira que envolve um complexo emaranhado de conexões interagentes, as quais impossibilitam a captação integral do fenômeno; dessa feita, procurou-se priorizar a exposição das principais correntes interpretativas em relação à solidariedade, comparando-as e tentando perceber suas limitações e incoerências.

Têm-se mais perguntas do que respostas, mas o que se pretende com este artigo é discutir os distintos contornos que envolvem a temática da solidariedade e seus desdobramentos no humano, considerando suas raízes biológicas, sua construção cultural e seus reflexos e impactos na arquitetura dos sistemas econômicos e sociais. A multiplicidade e a complexidade das variáveis interagentes se refletem em distintas compreensões em relação à natureza humana, ora entendendo-a como solidária, ora como competitiva ou, ainda, sem traços predefinidos, submetendo-se a construções histórico-culturais e políticas.

\section{Solidariedade e Sociobiologia}

A discussão em torno da própria natureza humana é fundamental quando se quer trabalhar temas que envolvem uma forte carga de valores morais e éticos, como é o caso da solidariedade. Conduzido pelo senso comum, há uma tendência a se perceber a solidariedade como algo consensual e intimamente ligado aos valores mais elementares do gênero humano, porém a busca em entender o fenômeno de forma mais aprofundada, e menos apaixonada, conduz-nos a visões mais complexas, que integram explicações distintas, que ora se confrontam ora se complementam e é nesse sentido que conhecimentos advindos de zonas de fronteira, como a sociobiologia e a antropologia, contribuem sobremaneira para melhor entender o fenômeno da solidariedade.

Edward O. Wilson (1994) foi um dos pioneiros da sociobiologia, área do conhecimento que parte da tese de que é possível compreender o comportamento humano e da própria sociedade por meio de explicações biológicas, descartando a vertente científica, que explica os fenômenos sociais a partir de uma lógica distinta. 0 autor afirma que as descobertas da neurobiologia sobre a mente humana aproximarão, 
inevitavelmente, as ciências humanas das ciências naturais, já que as ciências sociais ou humanas não podem ignorar os avanços da biologia e de outras ciências da natureza e essa proximidade eminente levará a estudar a sociedade, a cultura e até mesmo as questões ligadas à ética de uma forma totalmente diferente do que acontece atualmente em que a ciência ainda está vinculada a interesses de ideologias políticas e religiosas.

A corrente ligada à sociobiologia tende a privilegiar a importância da competição como mecanismo de sobrevivência e perpetuação da espécie, ou seja, estamos, por natureza, condicionados à competição como modo de evolução, e de forma oposta o altruísmo é percebido como uma característica que diminui as possibilidades de sobrevivência e de reprodução da própria vida. Aprofundando-se essa linha de raciocínio, conclui-se que o altruísta, em longo prazo, tenderia à extinção, enquanto proliferariam as espécies que manifestassem maior egoísmo e esforço na preservação do interesse individual. Essa ideia encontra suas bases fundamentadas na seleção natural de Darwin, a qual aponta a primazia da capacidade para competir como a garantia de perpetuação e evolução das espécies (DAWKINS, 2001).

Darwin avança na ideia de seleção natural apoiada em princípios meramente competitivos e propõe a noção de seleção de grupo como forma de explicar a existência do altruísmo e da solidariedade. Embora o comportamento altruísta não traga vantagens para o indivíduo isolado, estas advêm quando se analisa o grupo como um todo, em que formas mais organizadas de existência, confiabilidade mútua e coesão tendem a possuir maiores possibilidades de vitória ao disputar recursos naturais ou territórios com outros grupos menos organizados. Há, neste caso, uma seleção natural e competição baseada em grupos e não em indivíduos isolados, criando-se o conceito de seleção de grupo, ou seja, coopera-se para competir.

No início do século XX, os biólogos George C Williams e William Hamilton uniram genética e evolução, denominando-se de teoria sintética, em que inovaram ao atribuir uma importância singular aos genes na luta pela sobrevivência e na compreensão da evolução das espécies. De acordo com essa teoria, atribui-se primazia ao processo de supremacia de certos genes, como determinantes da evolução, o foco da seleção natural deixa de estar no indivíduo ou no grupo para ser atribuído aos genes que são passados entre gerações, no conceito de evolução de parentesco. A seleção natural não opera cegamente, 
de geração em geração, ela preserva os genes que trazem vantagens e elimina aqueles que trazem desvantagens aos organismos. Esta tese ressalta que a aptidão reprodutiva de um indivíduo não pode ser medida unicamente pelo número de filhos gerados, mas também inclui parentes próximos que carregam as partes de sua carga genética, o que é definido por Richard Dawkins (2001) com o conceito de "gene egoísta."

A premissa da perpetuação baseada na carga genética individual, compreendida pelo pensamento dos defensores da teoria sintética em que os genes buscam incessantemente fazer cópias de si mesmos ou de parentesco próximo, contrapõe-se à ideia de harmonia entre espécies, sendo esta alimentada mais por exemplos de natureza egoísta e individualista que de altruísmo e solidariedade. Até mesmo em comunidades tidas como exemplos de solidariedade natural, como no caso das colmeias, em que a cooperação é tida como irrepreensível, isto se explica pela quase totalidade de membros serem filhos da abelha rainha e logo carregarem o seu código genético, caso outras abelhas operárias resolvessem colocar ovos, estes seriam destruídos, pois o filho de uma irmã seria geneticamente mais distante que os filhos da rainha mãe; mais uma vez, o que se prioriza é a proximidade genética e não simplesmente a espécie. Ainda, de acordo com Dawkins (2001), o ser humano não ocupa um espaço à parte, mas antes segue o mesmo processo evolutivo e condicionado às mesmas leis da natureza.

$\mathrm{Na}$ década de 1970, Hamilton e Trivers desenvolveram uma nova teoria fundamentada no que chamariam de altruísmo recíproco, que tem como base prática a hipótese de que um auxilia o outro para ser auxiliado, colabora-se sempre que isto gere um retorno de proporções semelhantes. Este modelo apresenta como base a "teoria dos jogos", que busca explicar as diferentes hipóteses de disputas, considerando o processo de negociação de ganhos e perdas compensatórios. De forma prática, pode-se exemplificar esta teoria com abstrações retiradas das comunidades primitivas, nas quais os homens iam à caça e distribuíam os resultados da empreita por toda a tribo; isto se dava, pois se sabia que o que tinha sido vantajoso para um, num determinado dia, poderia não o ser nos demais, o que o fazia necessitar da reciprocidade como forma de sobrevivência (RIDLEY, 2000).

Waal (2010) parte de uma perspectiva distinta dos evolucionistas tradicionais que advogam em favor da primazia da competição e do egoísmo como elementos biológicos 
prioritários e desenvolve sua tese em torno da capacidade de empatia encontrada em diversos animais, principalmente, primatas próximos do ser humano. $\mathrm{O}$ autor defende que diferentes espécies foram dotadas, por meio do processo evolutivo, da capacidade de se colocar no lugar do próximo, de sentir o que o outro sente e, em alguns casos, até de se expor de forma a arriscar a própria vida para salvar a do outro. Essa compreensão da realidade contrapõe-se à prerrogativa tradicional em que os elementos competitivos e egoístas emergem como responsáveis pela perpetuação da vida na terra. A evolução da vida parece apontar para a existência de uma forma de empatia que perdura há centenas de milhões de anos e que é determinante na construção de grupos mais coesos e, por isso, mais fortes e que explica a sobrevivência diante das adversidades e de predadores mais poderosos.

De acordo com Waal (2010), os padrões de conduta na política e até a noção de solidariedade não são exclusivos dos humanos e podem ser encontrados em primatas parentes do homem, o que se explica por uma raiz biológica comum. Até mesmo questões como a moralidade, geralmente vistas como exclusividade do gênero humano, também se encontram em outros primatas, que apresentam capacidade de empatia e até senso de justiça, como pode ser observado nos macacos bonobos. Essa compreensão, então, obriga a se entender a moralidade, não mais como resultado apenas de uma construção cultural, mas de uma condição biológica. Sendo assim, a natureza é a criadora da base da vida em sociedade e não o homem.

Ainda que haja uma forte dosagem de elementos biológicos que condicionam a própria natureza humana, não se pode limitar a análise da evolução humana aos aspectos meramente biológicos, já que os fatores de natureza cultural desempenham um papel essencial na definição do humano e terão de ser impressos conjuntamente com os genéticos na compreensão da realidade. A nossa evolução, como seres humanos, sempre esteve condicionada à nossa capacidade de nos relacionarmos e interagirmos uns com os outros e com o meio em que habitamos. A necessidade de cooperação, à medida que se estabeleceram formas de divisão do trabalho cada vez mais complexas, exigiu relacionamentos cooperativos e altruístas que iam muito além do universo familiar, passando a haver a necessidade de novas formas de solidariedade baseadas em laços de cooperação com estranhos. Essas novas exigências sociais teriam exercido pressão sobre 
a seleção entre grupos humanos, favorecendo o surgimento da moral. Sendo que se a cultura está impregnada nos genes, também os genes dependem da cultura (RIDLEY, 2000).

O modelo das sociedades atuais está dominado pela valorização das atividades competitivas e o desestímulo às atividades cooperativas, no entanto, no modelo ecológico baseado nos ecossistemas, percebe-se que a competição e a cooperação estão sempre buscando um equilíbrio dinâmico, ao passo que o darwinismo social erra ao observar na natureza apenas a competição, não percebendo o nível molecular, mais sutil por natureza, em que se manifesta a cooperação em toda a sua extensão. Nos níveis subatômicos da física moderna, pode-se perceber que cada partícula não tem existência independente, sendo esta essencialmente um conjunto de relações interconectado numa infinidade de relações, ou melhor, não existem objetos, mas conexões. As relações estabelecidas entre partículas formam a matéria. Como afirma Capra (1996): "somos todos parte de uma teia inseparável de relações".

Há que se pensar baseando-se em processos e não em estruturas estanques. Podese usar a metáfora da música para melhor compreensão, em que cada nota tocada isoladamente não tem sentido, não apresenta harmonia, logo não pode ser identificada como música, a qual só se estabelece por meio de conexões, as relações estabelecidas entre diferentes notas é que formam a verdadeira música. Música, então, não é um conjunto de notas isoladas, mas ela só acontece mediante múltiplas e variadas relações que se formam (CAPRA, 2002).

Morin (2000) discorda da visão da sociobiologia que tenta fazer uma transposição da realidade biológica para a dimensão social humana. Na opinião do autor, trata-se de um reducionismo falho, já que não se podem estabelecer leis universais aplicáveis a qualquer fenômeno, principalmente, quando se trata de relações sociais construídas historicamente e determinadas culturalmente. Não existe um determinismo social, como advogam os defensores do determinismo biológico, considerando-se a capacidade humana de alterar a realidade à medida que se desenlaça, criando-se múltiplas possibilidades de resposta diante dos acontecimentos. O ser humano é muito mais que um simples modelo genético previamente condicionado, é repleto de elementos 
subjetivos que adentram no plano dos valores e da própria interpretação de mundo de cada um e de cada cultura.

A aceitação da teoria de Darwin e a sua transposição para as ciências sociais, naturalizando e reduzindo o ser humano à sua condição biológica, foi especialmente desenvolvida por Herbert Spencer, que a chamou de "sobrevivência dos mais aptos" e que se adequou muito bem à ideologia meritocrática e individualista dominantes, desde o século XVIII. Darwinismo e capitalismo formaram uma coesão que se apoiava na neutralidade e na inevitabilidade da ideologia hegemônica, o que passou a justificar as relações de dominação. Santos (2007) alerta para o fato de que a subjetividade da interpretação científica está condicionada à cultura e ao meio social em que esta está inserida; cada povo interpreta os fenômenos naturais de acordo com sua sociedade. Dessa forma, a compreensão dominante articula-se em torno de princípios socialmente construídos que são prioritariamente masculinos, ocidentais, individualistas, competitivos, exploratórios e antropocêntricos, sendo que qualquer explicação contrária a estas prerrogativas é vista como oposta à própria ciência.

\section{Competição e Individualismo ou Cooperação e Solidariedade}

Quando se analisam os diferentes projetos socioeconômicos que se confrontam numa sociedade e buscam hegemonia, despontam duas propostas distintas, que tanto se confrontam como se complementam e que dizem muito da própria visão em relação à natureza humana e de como devem ser estabelecidas as prioridades dentro da estrutura social. Nesse sentido, apresenta-se a corrente centrada em torno da solidariedade/cooperação, em oposição a que vê no individualismo/competição a forma mais eficiente de organizar a vida em sociedade e que se reflete em formas distintas de institucionalização, apontando para projetos diferentes de sociabilidade (BOBBIO, 2001).

A perspectiva individualista advoga a liberdade individual como bem maior, percebendo as instituições que visam proteger o trabalhador contra os riscos econômicos, como barreiras à expansão da própria atividade econômica, principal meio de ampliação do nível de emprego e do desenvolvimento social. Propõe-se, então, como solução o desmonte das instituições de bem-estar social e a desregulamentação do mercado de trabalho, principais entraves, segundo esta perspectiva, para a livre expansão 
das forças produtivas e do próprio desenvolvimento social. A vertente individualista entende as desigualdades entre indivíduos como inevitáveis, além de justificar a existência das desigualdades pelo fato de nem todos desempenharem o mesmo esforço e empenho, além de possuírem diferentes ambições materiais. Destaca-se, ainda, a variável sorte e os próprios dons inatos e meritocráticos de cada um como fatores determinantes e justificativos das desigualdades (FRIEDMAN, 1984).

Vale a pena recorrer ao pensamento de Adam Smith, considerado o pai da economia moderna, um dos primeiros pensadores a defender a primazia do individualismo e da competição como formas mais eficientes de organizar a vida social.

Não é da benevolência do açougueiro, do cervejeiro e do padeiro que esperamos o nosso jantar, mas da consideração que ele tem pelos próprios interesses. Apelamos não à humanidade, mas ao amor-próprio, e nunca falamos de nossas necessidades, mas das vantagens que eles podem obter (SMITH, 2010, p. 25).

Friedrich A. Hayek tornou-se um dos mais tradicionais defensores do liberalismo e do individualismo e, em seu livro "O Caminho da Servidão", publicado na Inglaterra, em 1944, Hayek (1990) fez um ataque apaixonado contra qualquer limitação dos mecanismos de mercado por parte do Estado, que denuncia como uma ameaça letal à liberdade, não somente econômica, mas também política. Ele defende a primazia absoluta da liberdade, devendo ser banida qualquer proposta que venha atentar contra este ideal maior. Hayek compartilha dos ideais de Adam Smith, mas vai além ao destacar a importância da informação e de seus inúmeros agentes que só conseguem ser coordenados e viabilizados por meio dos mecanismos de mercado, independentemente dos ideais competitivos ou cooperativos de cada um, não havendo a hipótese deste conjunto ilimitado de informações ser apreendido por um único organismo coordenador.

Chamar de privilégio a propriedade privada como tal, que todos podem adquirir segundo as mesmas normas, só porque alguns conseguem adquiri-la e outros não, é destruir a palavra privilégio do seu significado. A liberdade econômica [...] constitui o requisito prévio de qualquer outra liberdade. [...] cheguei à conclusão de que o maior serviço que ainda posso prestar ao meu semelhante é fazer com que os oradores e escritores se sintam profundamente envergonhados cada vez que empregarem o termo 'justiça social' (HAYEK, 1990, p. 92). 
O autor denuncia que qualquer tipo de planificação da economia é o caminho para o totalitarismo, partindo do princípio de que a vida econômica é constituída de indivíduos egoístas que perseguem fins diferentes, concorrentes e até antagônicos. Não existe racionalidade superior a dos indivíduos, a única racionalidade efetiva é resultante do equilíbrio das ações individuais. O totalitarismo é resultado natural do abandono do liberalismo, não podendo haver liberdade política se não a liberdade econômica. A liberdade individual é a melhor forma de desenvolvimento da sociedade, já que por intermédio da busca de cada um por seus interesses particulares, consegue-se estabelecer certo equilíbrio, jamais atingido por meio de regulagens centralizadas. Uma economia é um sistema demasiado complexo para ser planejado por uma instituição central e, por isso, ela deve evoluir livremente, devendo qualquer intervenção de natureza solidária ficar restrita ao plano microssocial voluntário e individual e não se dar no nível macrossocial de política pública de Estado (HAYEK,1990).

A visão de solidariedade, de acordo com Hayek (1990), apoia-se no pensamento evolucionista, em que a solidariedade não passa de um instinto animal, comum a pequenos grupos, que deverá ser superado, caso haja interesse em níveis mais elevados de desenvolvimento. A evolução da sociedade não teria sido possível se vigorasse a supremacia do princípio da solidariedade de todos para com todos, não sendo condizente com a ordem do mercado competitivo, como motor principal do desenvolvimento das sociedades. A solidariedade é até compreensível para Hayek, no plano microssocial, mas jamais extrapolada para a dimensão institucional do macrocosmos.

Friedman (1984), de forma semelhante, notabilizou-se por defender e impulsionar a doutrina econômica liberal, embora o centro da sua discussão esteja na defesa do mecanismo do mercado como garantia de prosperidade e de utilidade, "ser livre para escolher". Defende a liberdade individual e considera qualquer medida de intervenção, como coercitiva e, por conseguinte, abusiva, partindo do princípio de que toda a tentativa de redistribuição de renda, apoiando-se na lógica de tirar dos mais ricos para distribuir aos mais pobres, via tributação, é um atentado à liberdade individual e ao próprio mérito. 


\begin{abstract}
A essência da filosofia liberal é a crença na dignidade do individuo, em sua liberdade de usar ao máximo suas capacidades e oportunidades de acordo com suas próprias escolhas, sujeito somente à obrigação de não interferir com a liberdade de outros indivíduos fazerem o mesmo [...] Todos os homens têm o mesmo direito à liberdade. Este é um direito importante e fundamental precisamente porque os homens são diferentes, pois um indivíduo quererá fazer com sua liberdade coisas diferentes das que são feitas por outros [...] a igualdade entra imediatamente em conflito com a liberdade, sendo preciso, pois, escolher (FRIEDMAN, 1984, p. 177).
\end{abstract}

A corrente liberal busca justificar as diferenças sociais como responsabilidade única de cada indivíduo, de suas escolhas, esforços e da própria natureza. Os seguidores dessa corrente consideram a pobreza como decorrente da baixa produção proporcionada por estes indivíduos, o que poderia ser alterado se houvesse um esforço maior por parte de cada um, ou seja, ao produzirem mais aumentariam a riqueza, reduzindo as desigualdades, sendo a garantia de igualdade de oportunidades mais importante do que a igualdade de renda.

A lógica capitalista e, de forma particular, a neoliberal vê o processo de acumulação como um jogo em que todos competem e o ganho provém da utilidade que cada tarefa proporciona aos demais. Todo o processo se estabelece numa livre relação de compra e venda, sendo a acumulação o resultado da venda da utilidade de serviços superiores aos demais.

De forma distinta, a perspectiva estruturalista, que apresenta influências da corrente socialista clássica e do keynesianismo, defende que o mercado é imperfeito por natureza, não consegue estabelecer o equilíbrio automático e muito menos o pleno emprego. O mercado entregue à própria lógica sai de uma crise para outra infinitamente e jamais consegue estabelecer relações de equilíbrio justas e eficientes para o todo social (SINGER, 1998).

A corrente estruturalista entende o mercado como um jogo de forças em que se produzem inevitavelmente vencedores e perdedores, sendo indispensáveis as instituições públicas como meio de proteger os perdedores e os mais fragilizados. Nesse sentido, os estruturalistas apoiam-se na necessidade de intervenção direta do governo na vida econômica e social, proporcionando oportunidades equitativas e garantindo distribuição de renda justa, de forma que todos possam suprir suas necessidades básicas. Ao contrário 
da visão individualista, os estruturalistas entendem as razões da exclusão como estruturais, estando intimamente ligadas às diferentes estruturas organizacionais que compõem a economia e a sociedade e que acabam privilegiando certos grupos em detrimento de outros. Nesse sentido, Santos (1998, p. 69) reforça a importância da intervenção do Estado, não simplesmente em âmbito local, mas numa ação global articulada de forma comunicante:

O Estado nacional deve ser um elemento de uma rede internacional mais ampla, destinada a diminuir ou neutralizar o impacto destrutivo e excludente dos mecanismos imperativos hegemônicos do capital global, e reinverter o sentido destes na busca de uma redistribuição eqüitativa da riqueza globalmente produzida, porém todo o enriquecimento democrático será vão se a articulação estatal se restringir ao espaço nacional (SANTOS, 1998, p. 69).

Santos (1998) defende que o Estado deve transformar-se num campo de experimentação institucional, permitindo que diferentes soluções institucionais coexistam, em caráter de experiências-piloto, sujeitas à monitorização permanente de coletivos de cidadãos com vista a proceder à avaliação comparada dos desempenhos. $\mathrm{O}$ autor defende a criação de um espaço público não estatal, onde o Estado seja o elemento crucial de articulação e de coordenação, em que os demais agentes sociais possam manifestar-se de maneira democrática, em especial por meio de mecanismos, como orçamento participativo e fiscalidade participativa.

O Estado como coordenador das diferentes organizações, interesses e fluxos que emergem da desestatização da regulação social. A luta democrática é assim, antes de mais, uma luta pela democratização das tarefas de coordenação. Enquanto antes se tratou de lutar por democratizar o monopólio regulador do Estado, hoje há, sobretudo de lutar pela democratização da perda desse monopólio. As tarefas de coordenação são antes de tudo de coordenação de interesses divergentes e até contraditórios (SANTOS, 1998, p. 61).

Em termos econômicos, Santos e Rodrigues (2002) partem da necessidade de construção de uma nova lógica capaz de subjugar o econômico ao social na qual se deixe de reproduzir a estrutura dominante. Pensa-se em uma estrutura societal que seja capaz de se desenvolver de forma emancipatória, de baixo para cima, num processo de 
construção de poder comunitário que pode se desdobrar em iniciativas econômicas populares e articulação política, desconstruindo a lógica tradicional de que qualquer conquista ou desenvolvimento das camadas subalternas têm de estar condicionados ao sucesso das classes dominantes e se limitarem às franjas do próprio sistema.

A exclusividade de modelos ou de perspectivas de sociabilidade conduz a polarizações totalizadoras que, ao defenderem um único modelo de organização e de convivência, enfraquecem e desestruturam as outras dimensões. Faz-se necessário abraçar novas formas que contemplem a hibridez e a multiplicidade, em que Estados atuantes, socialmente, convivam com mecanismos de mercado e com organismos da sociedade civil, cada vez mais efetivos, ao que se aproxima do pressuposto de um socialismo de mercado, sendo este "uma combinação entre mecanismos de mercado e planejamento econômico, na qual o mercado tenha papel preponderante" (SANTOS; RODRIGUEZ, 2002, p. 43).

Os modelos que trabalham de forma polarizada em torno da solidariedade ou competição carregam em seu bojo uma característica que permeia o pensamento moderno: a disputa por um único princípio organizador da sociedade, pressupondo que não podem coexistir modelos mistos, ou diferentes aderências a cada modelo específico. A coexistência de diferentes modelos organizacionais parece ser mais condizente com a própria natureza humana, já que o indivíduo é composto por ambiguidades intrínsecas em que se expressam manifestações extremas de egoísmo e individualismo, assim como potencialidades solidárias e altruístas de dimensões superlativas.

\section{Considerações Finais}

Como já se antevia desde o início, a empreita desenvolvida, neste estudo, não traz respostas conclusivas, muito menos definitivas, mas trouxe à tona as diferentes explicações para um mesmo fenômeno e buscou ultrapassar as análises apressadas, e apaixonadas em boa parte dos casos, abarcadas pelo senso comum, que tende a interpretar a natureza humana de uma forma reducionista e apartada de contradições. Buscou-se, assim, renunciar à ideia ou ao projeto de solução definitiva e totalizadora e se aproximar dos pressupostos do pensamento complexo, que se apoia justamente na 
superação de um único princípio organizativo ou de uma única causa, implicando uma multiplicidade de causas e de efeitos para a explicação do mesmo fenômeno.

Na perspectiva da complexidade, emerge o pensamento de Edgar Morin (2005) que discute a questão da solidariedade de uma forma mais abrangente, compreendendo as diferentes faces que the são inerentes, o que faz com que o autor rejeite a ideia de um único ou predominante elemento de constituição da natureza humana. Somos vistos como seres multifacetados e com inúmeras potencialidades, não podendo ser reduzidos a um único princípio impulsionador de nossas condutas, mas antes apresentamo-nos como seres $100 \%$ solidários, ao mesmo tempo, que $100 \%$ competitivos e individualistas.

A contemporaneidade impõe abordagens plurais que consigam trabalhar em meio a ambientes caóticos, próprios da natureza humana, em que elementos díspares como competição e cooperação, individualismo e solidariedade têm que conviver. Como destaca Singer (2002), é difícil imaginar modelos viáveis, totalmente apartados de concorrência, como se presenciou, desastrosamente, na experiência soviética. Singer (2002) acredita que algum grau de concorrência faz-se necessário, a grande questão é a dose certa, para que não se caia no darwinismo capitalista, nem no corporativismo estatizante.

O grande problema de nosso tempo parece ser o monopólio exercido pelas forças de mercado, em que a concorrência e o individualismo dominam todas as esferas da vida social, de forma desproporcional e alienante. Tudo se torna simples mercadoria em que a instabilidade e a imprevisibilidade são vistas como inevitáveis. A competição invadiu praticamente todos os espaços, desde nações, organizações, regiões, escolas, esportes, igrejas e até famílias. Nada escapa ao domínio do individualismo como lógica da vida em sociedade. Presencia-se a redução progressiva e acelerada da degradação dos espaços pessoais e sociais que não apresentam valor comercial e, assim, assiste-se à minimização ou descaracterização dos princípios da solidariedade, cooperação, afetividade, amor e compaixão, entre tantas outras dimensões fundamentais à nossa identidade, desenvolvimento e mesmo sobrevivência como espécie.

O que se quer aqui reforçar é a necessidade de se acolherem novas experiências societais, tanto no plano microssocial, como no macrossocial, no plano local como no global, que possam obstaculizar o avanço irrestrito e desproporcional do paradigma 
competitivo individualista. Destacam-se aqui, as experiências de economia solidária, que apresentam uma nova lógica organizacional, os diversos movimentos sociais, as inúmeras e variadas entidades da sociedade civil, os fóruns, como o fórum social mundial, além de movimentos em favor do perdão da dívida externa dos países de terceiro mundo, propostas de renda básica de cidadania, movimentos em apoio à criação de um imposto de transações financeiras mundiais destinado a um fundo de combate à miséria, entre muitas outras iniciativas que tentam lutar contra o monopólio do individualismo nas estruturas sociais dominantes.

\section{Referências}

BOBBIO, N. Direita e esquerda. São Paulo: UNESP, 2001.

CAPRA, F. A teia da vida: uma nova compreensão científica dos sistemas vivos. São Paulo: Cultrix, 1996.

As conexões ocultas: ciência para uma vida sustentável. São Paulo: Cultrix, 2002.

DAWKINS, R. O gene egoísta. Belo Horizonte: Itatiaia, 2001.

DEMO, P. Solidariedade como efeito de poder. São Paulo: Cortez; Instituto Paulo Freire, 2002.

FRIEDMAN, M. Capitalismo e liberdade. São Paulo, Abril Cultural, 1984.

HAYEK, F. O caminho da servidão. 5. ed. Rio de Janeiro: Instituto Liberal, 1990.

MORIN, E. Os sete saberes necessários à educação do futuro. São Paulo: Cortez, 2000. . Introdução ao pensamento complexo. Porto Alegre: Sulina, 2005.

RIDLEY, M. As origens da virtude: um estudo biológico da solidariedade. Rio de Janeiro: Record, 2000.

SINGER, P. Globalização e desemprego: diagnóstico e alternativas. São Paulo: Contexto, 1998.

. Introdução à economia solidária. São Paulo: Fundação Perseu Abramo, 2002.

SANTOS, B. de S. Reiventar a democracia: entre o pré-contratualismo e o póscontratualismo. Lisboa: Gradiva, 1998.

A crítica da razão indolente: contra o desperdício da experiência. São Paulo:

Cortez, 2007. v. 1. 
SANTOS, B. de S.; RODRIGUES, C. Introdução. In: SANTOS, B. de S. (Org.). Produzir para viver: os caminhos da produção não capitalista. Rio de Janeiro: Civilização Brasileira, 2002.

POLITO, A. G. Michaelis dicionário de sinônimos e antônimos. São Paulo: Melhoramentos, 2009.

FERREIRA, A. B. de H. Dicionário Aurélio da língua portuguesa. Positivo-Livros, 2010.

SMITH, A. A riqueza das nações: investigações sobre sua natureza e suas causas. São Paulo: Folha de S. Paulo, 2010. v. 1.

WAAL, F. de. A era da empatia. São Paulo: Companhia das Letras, 2010.

WILSON, E. O. Diversidade da vida. São Paulo: Companhia das Letras, 1994.

Recebido em: 11/11/2010

Aprovado em: 12/12/2010 